\title{
Uji Efek Antipiretik Air Perasan Rimpang Jahe Merah (Zingiber officinale var. rubrum) pada Tikus Putih (Rattus norvegicus) Jantan Galur Wistar yang Diinduksi Ragi Roti
}

\author{
Ari Viandri Wismananda ${ }^{1}$, Fathiyah Safithri ${ }^{1}$, Dwi Nurwulan Pravitasari ${ }^{1}$ \\ ${ }^{1}$ Pendidikan dokter, Fakultas Kedokteran,Universitas Muhammadiyah Malang \\ Email: ariviandri@gmail.com
}

\begin{abstract}
ABSTRAK
Latar Belakang: Demam dapat diatasi dengan menggunakan parasetamol. Pemberian parasetamol lebih dari dosis yang dianjurkan pada anak usia kurang dari 2 tahun selama \pm 1 hari telah terbukti sebagai risiko hepatotoksisitas. Rimpang jahe merah mengandung gingerol dapat memberikan efek antipiretik dengan cara menghambat pembentukan prostaglandin dan menstimulasi produksi IL-10.

Tujuan: Untuk mengetahui apakah air perasan rimpang jahe merah (Zingiber officinale var. rubrum) dapat memberikan efek antipiretik pada tikus putih (Rattus norvegicus) jantan galur wistar yang diinduksi ragi roti.

Metode: Penelitian true experimental menggunakan 24 ekor tikus yang dibagi menjadi 4 kelompok. Setelah 4 jam diinduksi ragi roti, kelompok pertama diberikan aquades per oral. Kelompok kedua, ketiga, dan keempat diberikan dosis perasan rimpang jahe merah sebesar $70 \mathrm{mg} / \mathrm{kgBB}, 140 \mathrm{mg} / \mathrm{kgBB}$, dan $210 \mathrm{mg} / \mathrm{kgBB}$ per oral.

Hasil Penelitian dan Diskusi: Perasan rimpang jahe merah dosis $140 \mathrm{mg} / \mathrm{kgBB}$ dan $210 \mathrm{mg} / \mathrm{kgBB}$ menunjukkan asil yang signifikan dalam menghambat peningkatan suhu rektal tikus dan menurunkan suhu rektal tikus yang diinduksi ragi roti $(\mathrm{p}<0,05)$. Dosis yang memberikan efek antipiretik paling besar adalah 210 $\mathrm{mg} / \mathrm{kgBB}$.

Kesimpulan: Air perasan rimpang jahe merah dapat memberikan efek antipiretik pada tikus putih jantan galur wistar yang diinduksi ragi roti.

Kata Kunci: Antipiretik, perasan rimpang jahe merah, ragi roti.
\end{abstract}

\section{ABSTRACT}

Background: Fever can be surmounted by using paracetamol. Giving paracetamol more than the dosage that recommended in children aged less than 2 years for \pm 1 day has proven to be a risk of hepatotoxicity. Red ginger rhizome contains gingerol that may provide antipyretic effect by inhibiting the formation of prostaglandin and stimulate the production of IL-10.

Objective: To determine whether red ginger rhizome juice (Zingiber officinale var. rubrum) may provide antipyretic effects on male wistar rats (Rattus norvegicus) that were induced by baker's yeast.

Method: True experimental research used 24 rats, divided into four group. After 4 hours of injection Baker's yeast-induced fever, the first group was given aquades orally. The second, third, and fourth group were given red ginger rhizome juice at doses $70 \mathrm{mg} / \mathrm{kgBW}, 40 \mathrm{mg} / \mathrm{kgBW}$, and $210 \mathrm{mg} / \mathrm{kgBW}$ orally.

Result and Discussion: Red ginger rhizome juice at doses $140 \mathrm{mg} / \mathrm{kgBW}$ and $210 \mathrm{mg} / \mathrm{kgBW}$ significantly inhibited the increase body temperatures of rats and lowering the body temperatures of rats that induced by Baker's yeast $(\mathrm{p}<0,05)$. The dose that gives the greatest antipyretic effect is $210 \mathrm{mg} / \mathrm{kgBW}$.

Conclusion: Red ginger rhizome juice provided antipyretic effects on male wistar rats that were induced by baker's yeast.

Key word: Antipyretic, red ginger rhizome juice, baker's yeast. 


\section{PENDAHULUAN}

Demam, juga dikenal sebagai pireksia, adalah kondisi medis umum yang ditandai dengan peningkatan suhu di atas kisaran normal $36,5-37,5^{\circ} \mathrm{C}\left(98-100^{\circ} \mathrm{F}\right)$ akibat adanya peningkatan set-point suhu tubuh ${ }^{1}$. Demam pada tahun 2013 menduduki peringkat ke6 dari 11 besar morbiditas dan mortalitas anak balita di pasien rawat inap dan menduduki peringkat ke-2 dari 10 besar morbiditas dan mortalitas anak balita di pasien rawat jalan ${ }^{2}$.

Kenaikan suhu tubuh (suhu rektal di atas $38^{\circ} \mathrm{C}$ ) pada anak berumur 6 bulan sampai 5 tahun dapat menimbulkan suatu bangkitan kejang atau disebut dengan kejang demam ${ }^{3}$. Berdasarkan data yang diperoleh dari ruang bangsal anak RSUD Kabupaten Bekasi pada bulan Desember 2012, Januari 2013 dan Februari 2013, prevalensi anak yang mengalami kejang demam pada bulan Desember 2012 adalah 11,9\%, bulan Januari 2013 18,18\%, dan pada bulan Februari $201316,98 \%^{4}$.

Asetaminofen atau parasetamol adalah jenis obat golongan antipiretik yang paling luas digunakan di seluruh dunia ${ }^{5}$. Pemberian parasetamol lebih dari dosis yang dianjurkan (>90 $\mathrm{mg} / \mathrm{kg} / \mathrm{hari})$ pada anak usia kurang dari 2 tahun selama lebih dari satu hari terbukti beresiko menyebakan hepatotoksisitas yang ditandai dengan peningkatan serum Serum Glutamic Pyruvate Transaminasem (SGPT) dan Serum Glutamic Oxaloacetic Transaminase (SGOT) ${ }^{6}$.
Jahe merupakan tanaman rimpang yang paling banyak dimanfaatkan sebagai antipiretik dibandingkan tanaman suku Zingiberacea lainnya, seperti lengkuas, temulawak, temu ireng, temu kunci, dan lain-lain ${ }^{7}$. Komponen utama dari jahe merah segar adalah senyawa homolog fenolik keton yang dikenal sebagai gingerol. Kandungan gingerol pada jahe merupakan inhibitor biosintesis prostaglandin yang lebih poten dari indometasin dan meningkatkan produksi interleukin-10 (IL-10) yang merupakan antipiretik endogen ${ }^{8,9}$. Proses pengolahan terutama yang menggunakan pemanasan ternyata akan menurunkan kadar gingerol. Gingerol sebagai komponen utama rimpang jahe merah dengan proses pemanasan dapat terkonversi menjadi shogaol atau zingero ${ }^{10}$.

Berdasarkan uraian diatas, penulis tertarik mekakukan penelitian mengenai efek antipiretik air perasan rimpang jahe merah (Zingiber officinale var rubrum) terhadap tikusputih (Rattus norvegicus) jantan galur wistar yang diinduksi ragi roti.

\section{METODE PENELITIAN}

Bahan dan instrument yang digunakan adalah ragi roti, rimpang jahe merah, aquades, $\mathrm{NaCl} 0,9 \%$, vaseline, alat pemeliharaan tikus (kandang tikus, penutup kandang dari anyaman kawat, botol air, timbangan), alat pembuatan air perasan rimpang jahe merah (pisau, parutan, kain bersih), alat pengukur suhu (ThermoOne Alpha 3), sonde oral, botol kaca, spuit, jarum suntik, kapas alkohol, tissue, spidol, dan 
handscoon

\section{Tahap Persiapan Hewan Coba}

Tikus diadaptasikan dalam kandang kurang lebi selam 1 minggu untuk proses aklimatisasi. Selama proses tersebut, dijaga agar kebutuhan makan dengan pakan standar terpenuhi yaitu 12 gram 20 gram perhari, air minum tetap terpenuhi dan kandang tetap bersih dengan mengganti sekam tiga hari sekali ${ }^{11}$.

Sebelum percobaan dilakukan, tikus dipuasakan (hanya diberikan aquades tanpa diberikan makanan) selama 6 jam. Keberadaan makanan dalam lambung seringkali mengganggu proses absorbsi obat, sehingga terjadi manipulasi efek obat, maka dari itu tikus harus dipuasakan terlebih dahulu sesuai dengan waktu yang diperlukan untuk pengosongan lambung yaitu 6 jam $^{11}$.

\section{Pembagian Kelompok Hewan Coba}

Tikus yang digunakan 24 ekor, dibagi menjadi 4 kelompok dan masing- masing kelompok terdiri dari 6 ekor tikus.

a. Kelompok kontrol (aquades $3 \mathrm{ml}$ ).

b. Kelompok uji perasan rimpang jahemerah dengan dosis $70 \mathrm{mg} / \mathrm{kgBB}$ tikus.

c. Kelompok uji perasan rimpang jahe merah dengan dosis $140 \mathrm{mg} / \mathrm{kgBB}$ tikus.

d. Kelompok uji perasan rimpang jahe merah dengan dosis $210 \mathrm{mg} / \mathrm{kgBB}$ tikus.

Pembuatan Air Perasan Rimpang Jahe Merah a. Menimbang 500gram rimpangjahe merah segar.

b. Mencuci rimpang jahe merah dengan air mengalir untuk menghilangkan kotoran yang menempel pada jahe merah.

c. Mengupas bagian kulit rimpang jahe merah.

d. Menghaluskan rimpang jahe merah menggunakan parutan.

e. Memeras hasil parutan menggunakan kain bersih untuk memperoleh hasil akhir yang akan digunakan.

f. Memasukkan air perasan rimpang jahe merah ke dalam botol.

\section{Penentuan Dosis Air Perasan Rimpang}

\section{Jahe Merah}

Pemberian gingerol secara per oral dengan dosis $140 \mathrm{mg} / \mathrm{kgBB}$ menunjukkan efek antipiretik pada tikus. Dosis tersebut dijadikan sebagai dosis 2, dan dilakukan modifikasi pada dosis yang lainnya yaitu $70 \mathrm{mg} / \mathrm{kgBB}$ tikus sebagai dosis 1 dan $210 \mathrm{mg} / \mathrm{kgBB}$ tikus sebagai dosis $3^{8}$.

\section{Pemberian Dosis Air Perasan Rimpang Jahe}

\section{Merah}

Massa jenis air perasan rimpang jahe merah setelah dikur menggunakan piknometer adalah $0,83 \mathrm{gram} / 10 \mathrm{ml}$ dan berat tikus rata-rata pada penelitian ini adalah 200 gram. Berdasarkan massa jenis tersebut didapatkan besar volume air perasan rimpang jahe merah yang diberikan pada tikus secara peroral antara lain dosis 1 sebesar $0,168 \mathrm{ml}$, dosis 2 
sebesar 0,338ml, dan dosis 3 sebesar 0,506ml.

\section{Pembuatan Bahan Penginduksi Demam}

Induksi demam diberikan dengan cara pemberian ragi roti secara intraperitoneal dengan dosis sebesar $0,135 \mathrm{~g} / \mathrm{kgBB}$ dalam $\mathrm{NaCl} 0,9 \% 50 \mathrm{mg} / \mathrm{ml}$, kemudian diukur suhu tubuhnya secara per rektal setelah 4 jam induksi ${ }^{12}$

\section{Pengukuran Suhu Tikus}

Tikus dipegang dengan tangan kiri dan tangan kanan membersihkan anus tikus dengan kapas yang telah dibasahi dengan NS. Kemudian termometer rektal dioleskan pada vaseline dan dimasukkan ke dalam anus tikus selama 40-60 detik.

\section{HASIL PENELITIAN}

Berdasarkan hasil pengamatan suhu rektal tikus, rata-rata peningkatan suhu rektal tikus setelah diinduksi ragi roti $(\Delta S 0)$ dapat dihitung dari hasil pengurangan S0-Sx, rata-rata hambatan peningkatan suhu rectal tikus menuju suhu puncak demam $(\Delta \mathrm{S} 1)$ dapat dihitung dari hasil pengurangan S1-S0, sedangkan rata-rata penurunan suhu rektal tikus $(\Delta \mathrm{S} 2)$ dapat dihitung dari hasil pengurangan dari S1-S3.Hasil perhitungan tertera dalam tabel 1:

Tabel 1. Hasil $\Delta \mathrm{S} 0, \Delta \mathrm{S} 1$, dan $\Delta \mathrm{S} 2$

\begin{tabular}{|c|c|c|c|}
\hline INelomapok & 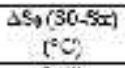 & $\begin{array}{c}\Delta 3_{1}(S 1-80) \\
(\mathrm{C})\end{array}$ & $\begin{array}{c}\Delta S:(S 1-55) \\
{[-C,}\end{array}$ \\
\hline 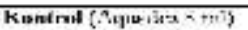 & $1 \%$ & $-10,14$ & 14 \\
\hline 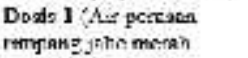 & 1,92 & $.0,05$ & 8.32 \\
\hline $\begin{array}{l}\text { deagan dssis } \\
73 \text { cul } k_{j} \text { SB) }\end{array}$ & & & \\
\hline 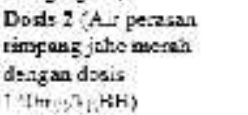 & 195 & $.0,33$ & $\sigma, t$ \\
\hline 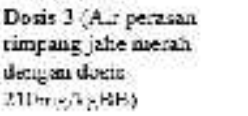 & 1,92 & $-0,37$ & 8,67 \\
\hline
\end{tabular}

Hasil Uji One Way Anova $\mathrm{p}=0,00(\mathrm{p}<0,05)$ terdapat perbedaan signifikan. Hasil Uji Post Hoc didapatkan nilai yang signifikan terjadi pada kelompok kontrol terhadap kelompok dosis 2 (140mg/kgBB) dan kelompok kontrol terhadap dosis 3 (210mg/kgBB). Hasil Uji Korelasi terdapat hubungan yang kuat

\section{PEMBAHASAN}

Penelitian ini membuktikan bahwa ragi roti dapat digunakan sebagai bahan penginduksi demam. Hal ini sesuai dengan penelitian Dubey et $a l^{12}$ yang menggunakan penginduksi ragi roti dengan dosis $0,135 \mathrm{~g} / \mathrm{kgBB}$ yang diencerkan menggunakan $\mathrm{NaCl}$ $0,9 \%$ sebesar $50 \mathrm{mg} / \mathrm{ml}$ untuk meningkatkan suhu tubuh tikus sebesar $1-3^{\circ} \mathrm{C}$. Ragi roti merupakan merupakan sel jamur non patogen yang bertindak sebagai pirogen eksogen ${ }^{13,14}$. Jika rag tersebut diinjeksikan masuk ke dalam tubuh secara intraperitoneal, maka sel-sel leukosit seperti makrofag, monosit, ataupun neutrofil akan memfagositosis pirogen eksogen tersebut dan akan mengeluarkan sitokin yang berperan sebagai pirogen endogen, seperti IFN, IL-6, TNF- $\alpha$, dan IL-1 ${ }^{15}$. Apabila sitokin ini masuk ke dalam otak baik secara 
aktif (pompa Na-K- ATPase) maupun secara pasif (difusi) dan berikatan dengan reseptornya, maka akan menyebabkan pelepasan asam arakidonat dari OVLT ataupun endotel pada area preoptik hipotalamus anterior dan akan dirubah menjadi PGE2 oleh enzim siklooksigenase. Prostaglandin E2 adalah 57.2\% mediator utama dari respon demam.

Penelitian ini membuktikan bahwa air perasan rimpang jahe merah mempunyai efek menghambat peningkatan suhu rectal tikus menuju suhu puncak demam. Hambatan peningkatan suhu ini diduga disebabkan oleh kandungan gingerol pada jahe Linear didapatkan besar pengaruh perasan rimpang jahe merah dalam menghambat peningkatan suhu rektal tikus adalah 59,4\% dan besar pengaruh perasan rimpang jahe merah dalam menurunkan suhu rectal tikus adalah merah. Penelitian menunjukkan bahwa gingerol pada rimpang jahe merah memiliki efek antipiretik mirip dengan parasetamol dan obat golongan antipiretik lainnya yaitu menghambat enzim siklooksigenase $^{7,8}$. Apabila enzim siklooksigenase dihambat, maka tidak akan terjadi perubahan asam arakidonat menjadi PGE2, sehingga PGE2 tidak terbentuk dan demam dapat dihindarkan. Penelitian ini membuktikan bahwa air perasan rimpang jahe merah mempunyai efek menurunkan suhu rektal tikus. Penurunan suhu rektal tikus ini diduga disebabkan oleh kandungan gingerol pada jahe merah. Penelitian menunjukkan bahwa gingerol pada rimpang jahe merah dapat meningkatkan produksi IL-10 yang berfungsi sebagai antipiretik endogen ${ }^{9}$. Sehingga apabila produksi IL-10 semakin banyak, maka penurunan suhu semakin besar.

\section{SIMPULAN}

1. Air perasan rimpang jahe merah (Zingiber officinale var. rubrum) dapat memberikan efek antipiretik pada tikus putih jantan galur wistar yang diinduksi ragi roti.

2. Terdapat hambatan peningkatan suhu rektal tikus putih (Rattus norvegicus) jantan galur wistar yang diinduksi ragi roti setelah pemberian air perasan rimpang jahe merah (Zingiber officinale var. rubrum).

3. Terdapat penurunan suhu rektal tikus putih (Rattus norvegicus) jantan galurwistar yang diinduksi ragi roti setelah pemberian air perasan rimpang jahe merah (Zingiber officinale var. rubrum).

4. Dosis air perasan rimpang jahe merah(Zingiber officinale var. rubrum) yang memberikan efek antipiretik paling besar pada tikus putih jantan galur wistar yang diinduksi ragi roti adalah 210 $\mathrm{mg} / \mathrm{kgBB}$.

\section{DAFTAR PUSTAKA}

1. Anochie, Ifesinachi P,2013, Mechanisms of Fever in Humans, International Journal of Microbiology and Immunology Research, Vol. 2(5), pp. 37-43.

2. Kemenkes RI (Kementrian Kesehatan Republik Indonesia), 2015, InfoDATIN Pusat Data dan Informasi Kementrian Kesehatan RI, ISSN 2442- 
7659, April 2015, pp. 4-5.

3. Arief RF, 2015, Penatalaksanaan Kejang Demam, KalbeMed, Vol. 42(9), pp. 658-661.

4. Nisa H, 2012, Hubunganm Tingkat Pengetahuan Ibu Dengan Kejadian Kejang Demam Pada Balita Di RSUD Kabupaten Bekasi Tahun 2012, Ilmu Kesehatan Medistra Indonesia, Bekasi, Vol. 1, pp. 1-2.

5. Jurnalis YD, Sayoeti Y, Moriska M, 2015, Kelainan Hati akibat Penggunaan Antipiretik, Jurnal Kesehatan Andalas, Vol. 4(3), pp.978-887.

6. Shivbalan S, Sathiyasekeran M, Thomas K, 2016, Therapeutic misadventure with paracetamol in children, Indian Journal of Pharmacology, Vol. 42 (6), pp. 27, viewed 1 Mei 2017, <https://www.ncbi.nlm.nih.gov/pmc/articles/PMC-2991705/>.

7. Kuntorini EM, 2015, Botani Ekonomi Suku Zingiberaceae sebagai Obat Tradisional oleh Masyarakat di Kotamadya Banjarbaru, BIOSCIENTIAE, Vol. 2(1), pp. 25-36.

8. Bone K, 2012, Ginger The Herbal Aspirin? Part 2, MediHerb Professional Review, Vol.53, pp.1-3.

9. Mindell, 2009, Easingthe Pain Naturally with Ginger, Vol 1, Read How You Want, pp. 119.

10. Hernani, Winarti C, 2011, Kandungan Bahan Aktif Jahe dan Pemanfaatannya Dalam Bidang Kesehatan, Balai Besar Penelitian dan Pengembangan Pascapanen Pertanian, pp. 125142.

11. Lucia EW, 2011, Eksperimen Farmakologik Orientasi Preklinik, Surabaya: Sandira Surabaya, pp. 10.

12. Dubey N, Dubey N, Mehta RS, 2009, Physicochemical and Pharmacological Assessment of A Traditional Biomedicine:ukta houktic Bhasma, Songklanakarin Journal of Science and Technology, 31 (5), pp. 501-510.

13. Ayodeji O, Adebola R, Adeniyi H,2016, Antipyrectic And Antinociceptive Activities of Ethanolic Extract Of Eugenia Aromatica Baill Seeds, IOSR Journal Of Pharmacy, Vol. 6, pp. 2833.

14. Milton AS, 2012, Handbook of Experimental Pharmacology, Vol. 60, University of Aberdeen, Marischal College Department of Pharmacology, New York, pp. 205.

15. Dalal S, Zhukovsky DS, 2007, Pathophysiology and Management of Fever, The Journal Of Supportive Oncology, Vol. 4(1), pp.9-1 